\title{
"Dynamite Scrupulously Packed": A Revaluation of Henry Blake Fuller's Bertram Cope's Year
}

https://doi.org/10.51897/interalia/RUMA9891

\author{
Nils Clausson \\ University of Regina \\ ORCID: 0000-0003-0912-0749
}

\begin{abstract}
The essay proposes a reinterpretation and revaluation of Henry Blake Fuller's 1919 novel Bertram Cope's Year and argues that it deserves permanent currency within the canon of gay fiction. My reinterpretation and revaluation of it is based on the premise that readings of it over the past 50 years (since Edmund Wilson's 1970 essay on Henry Blake Fuller's fiction in the New Yorker) have failed to understand its representation of homosexuality. Criticism of the novel has been based on post-Stonewall assumptions of what a 'gay novel' should be and what cultural work is should perform. The post-Stonewall paradigm of the gay novel is that it is a comingof-age story, a Bildungsroman, focused on a protagonist who, through a process of self-discovery, arrives at an acceptance and affirmation of his sexual identity. The prototype is Edmund White's A Boy's Own Story, with E. M. Forster's Maurice a precursor. To appreciate Bertram Cope's Year, we must, I argue, abandon post-Stonewall presuppositions of what we should expect from a gay novel. Bertram Cope's Year is not a coming-of-age novel. Rather it is a comic novel formed from Fuller's successful fusion and subversion of the romantic comedy, the comedy of manners, and the campus novel. Bertram Cope is a comic hero who ultimately triumphs over the efforts of a college town, presided over the matchmaking socialite Medora Phillips, to marry him to one of the three young ladies in her circle. He is rescued from this unwanted marriage by his boyfriend, who arrives to save him from the unwanted marriage. Fuller successfully exploits the conventions of the comic novel to tell a story that anticipates one of the aspirations of the gay liberation movement half a century later. As such, it deserves permanent currency.
\end{abstract}

Keywords: Henry Blake Fuller, Bertram Cope's Year, gay canon, comedy of manners

"Compressed form is itself one of the manifestations of force - an evidence of vigor." - Henry Blake Fuller, A Plea for Shorter Novels

How do we read and, more importantly, judge a "gay" novel written and published long before the emergence of a modern, post-Stonewall gay sensibility and consciousness? What is required to forestall readers today from imposing their expectations and assumptions on the past so that they can appreciate a pre-Stonewall novelist's art of fiction? These are the questions raised by postStonewall responses to Henry Blake Fuller's novel Bertram Cope's Year, privately printed in Chicago by Fuller in 1919, after he had tried, unsuccessfully, to find a New York publisher for it. In the words of Carl Van Vechten, writing in 1922, the novel "drop[ped] from the presses still-born, to meet with absolute silence on the part of the reviewers, and to find itself quickly on sale at the "remainder" tables of the large department stores" (140). A disappointed Fuller burned the manuscript together with the unsold copies, and the novel was virtually forgotten until it was reprinted in 1998 by Turtle Press, and then reprinted later that year by the Quality Paperback Book Club in its Pink Triangle series. 
A positive review of the Turtle Press edition in The New York Times Book Review did little to win the book a wide readership, although that edition, with an introduction by Edmund Wilson, might have been a factor in getting Fuller named posthumously to The Chicago LBGT Hall of Fame in 2000. So it is not all that surprising, then, that in 2014 when the Gay and Lesbian Review asked "What Was the First Gay Novel?" Bertram Cope's Year was not among the eight novels the editors nominated for that distinction ${ }^{1}$. Instead of continuing neglect, the novel deserves permanent currency as one of the masterpieces of the gay canon for its unprecedented acceptance of a gay male relationship as wholesome, unproblematically normal, and hence unobjectionable, as well as for its affirmation of the subversive force of the homoerotic.

It is not difficult to see why Bertram Cope's Year has failed to achieve canonical status. Half a century after Stonewall, the novel's apparent reticence in portraying gay experiences, particularly sex, will seem to most readers outdated, even prudish. The nude swimming scene will not elicit recollections of the homoerotic paintings of Fuller's English contemporary, Henry Scott Tuke. "The novel treads gently around the edge of the erotic," says Andrew Solomon in his "Afterword" (291). "For readers responsive to the uninhibited fiction of Edmund White, Dale Peck, David Leavitt and others," observed Joel Connaroe in his 1998 review, "Fuller's approach to sensuality will seem almost comically prim" (13). The novel certainly does not advocate modern gay liberation, personal or political. Although there are three and likely four gay characters in a novel that Edmund Wilson thought was "not really a book about homosexuality" (xxvii), none of them comes close to exhibiting a postStonewall consciousness of his sexual identity or confronts the challenge of living an openly gay life. So for today's reader there are rather a lot of obstacles to overcome.

The problem that critics both inside and outside the academy have struggled, with varying degrees of failure, to grapple with is how to take the novel's representation of and attitudes to homosexuality. Although Carl Van Vechten wrote perceptively about the novel in 1922 - in a letter to him Fuller called his commentary "the only intelligent one I have encountered" (qtd. in Scambray, 153) - modern criticism of it begins with Edmund Wilson's seminal reappraisal of Fuller, which appeared in The New Yorker in May 1970, not quite a year after Stonewall, and was reprinted in 1998 in both the Turtle Press and Quality Paperback Book Club editions. At the time, Wilson was still one of the most influential and respected literary critics and public intellectuals in New York. Who better to make the case that Fuller's novels, and specifically Bertram Cope's Year, deserve permanent currency? Wilson was trying to get critical recognition of Fuller's entire oeuvre (he discusses all his novels), and he singles out Bertram's Cope's Year for especial praise, calling it "perhaps Fuller's best" and regretting that "it seems never to have had adequate attention" (xxx). Yet, despite his praise of it, Wilson could still declare that it was not really about homosexuality, claiming: "At no point has the reader been given any clue as to Bertram's sexual inclinations" (xxx). (There are only slightly fewer clues than in

\footnotetext{
${ }^{1}$ Richard Schneider, Jr., "Special Issue: 'The First Gay Novel.'" The Gay \& Lesbian Review 21.6 (Nov.-Dec. 2014), pp. 4-5. The six novels nominated were The Picture of Dorian Gray, Remembrance of Things Past, Maurice, The Well of Loneliness, The City and the Pillar, Giovanni's Room, A Single Man, and The Charioteer. The issue included essays on all the nominees.
} 
one of Joseph Hansen's Dave Brandstetter mysteries.) Deliberately downplaying the homosexual theme, Wilson argues that the novel "has a kind of philosophic theme," namely "the power exerted by a 'charismatic' personality, extended to what was then the conventional range" of the realist novel (xxxi). Wilson set the precedent for later critics, who have repeatedly tried to identify the "real" subject of the novel, and post-Stonewall critics, with very few exceptions, share Wilson's ambivalence. Praise for the novel, when it comes at all, is always qualified. Writing four years after Wilson, Bernard Bowron acknowledges the homosexual theme, but like Wilson he believes that the "major theme" lies elsewhere. The novel, he says, is really "about the careless ingratitude of youth toward yearningly helpful middle age. And, with uncharacteristic daring, Fuller wove into this major theme a restrained but quite undisguised treatment of homosexuality" (226). It is hardly surprising, then, that he dismisses it as "not a very interesting novel" (227), or that Joel Conarroe finds its enduring value in its "beautifully evoked period atmosphere, its sly humor and its picturesque diction" (13). This comes close to damning with faint praise.

Writing nearly two decades after Stonewall, Kenneth Scambray deals much more directly with the homosexual theme, yet still finds Fuller's inadequate treatment of it to be the novel's major weakness, which he attributes to Fuller's unwillingness to portray his protagonist's homosexuality with sufficient psychological complexity for fear that doing so would reveal his own (repressed) sexuality:

Cope is a weakly drawn character, but given the limitations that Fuller was working under, Cope's irresolute nature is somewhat understandable. A deeply probing psychological view of Cope's character and the conflict he faced as a homosexual in Churchton would have exposed far too much about Fuller. A more socially assertive Cope would have caused him to challenge more directly and more openly the values of those around him. [...] This would have been far too revealing and even dangerous for Fuller. [...] Fuller realized that if he exposed his protagonist more, according to contemporary views of homosexuality, Cope would have been judged either insane or morally decrepit. To have his novel read at all, the only route open to Fuller was a circuitous one. (150)

Scambray's implied assumption is that to be successful Fuller's novel - indeed, any gay novel - must deal openly with the protagonist's sexuality and offer "a probing psychological view of his character" in the way that, for example, Edmund White does in A Boy's Own Story (1982), or David Leavitt in The Lost Language of Cranes (1986). For Scambray, Cope is "weakly drawn" because Fuller could not in 1919 write openly about his protagonist's sexuality. Cope's weakness translates into the weakness of the novel. Similarly, Roger Austen criticizes Fuller for failing to write about gay relationships "with understanding and incisive candor" because to do so would have revealed too much about himself (30). 
But even if we grant the limitations Fuller was working under (most novelists have worked under at least some limitations imposed by their times), critics like Scambray still fail to recognize that, although Fuller never intended the novel to be a "deeply probing psychological" representation of a gay man coming to terms with his sexual identity, he still managed to work successfully within those limitations and strike an early blow for what would, half a century later, be called gay liberation. Fuller deserves recognition and praise for writing the first novel to tell the story of a gay man who, with the support of his lover, successfully negotiates the pressures of being gay in an unsupportive society that not only lacks models of how to be openly gay but that also tries - although it ultimately fails - to subject him to heterosexual norms, specifically marriage. This was no insignificant achievement in 1919. In portraying two male lovers' rejection of and ultimate triumph over the restrictive and conformist society of a provincial mid-Western college town, Bertram Cope's Year is one of the first novels to anticipate a basic principle of the 1970s gay liberation movement and its subsequent evolution. Fuller deserves recognition for what he achieved, not criticism for what he did not even try to do. To gain that recognition, a revaluation of the novel must address four critical issues: critics' inappropriate post-Stonewall expectations of what a gay novel should be and do; the novel's indebtedness to the tradition of dramatic comedy and Bertram Cope's characterization as a comic figure; Fuller's subtle yet sophisticated treatment of the erotic in the novel, and Arthur Lemoyne's subversive role as the embodiment of the erotic.

To these four I would add the aesthetic criterion implied by my epigraph: Fuller's complete and assured mastery of form and style. Fuller, like the modernist novelists who were his contemporaries, was very much preoccupied with the form and art of fiction. He acknowledged the importance of form in an article on him by Charles C. Baldwin in which Fuller said, "As may be gathered, I am as much interested in form and technique as with any of the other elements involved in fiction; all because these two features seem to be increasingly disregarded by the ordinary reader" (194). And in an essay written just two years before the publication of Bertram Cope's Year, he affirmed: "'Real art' is, and will remain, largely a matter of form, of organism, of definition, of boundaries. The artist will express his interest [...] but it must be an interest disciplined by, and within metes and bounds, an interest which will result in a disciplined impression" ("A Plea," 141).

In my view, the major obstacle to reassessing the novel is that in the decades after Stonewall the criterion for evaluating a gay novel has been inseparable from the privileged position in the gay canon enjoyed by the coming-of-age/coming-out novel. This criterion has meant that pre-Stonewall novels are often interpreted and judged - or rather misinterpreted and misjudged - from a postStonewall perspective. This critical practice and the judgments that follow from it are clearly exemplified by Mark Lilly's analysis and evaluation of David Leavitt's The Lost Language of Cranes (1986) in his book Gay Men's Literature in the Twentieth Century (1993):

The Lost Language of Cranes is an outstanding example of the recent tradition of coming out novels, many examples of which appeared in the 1970s and 1980s. The 
formula normally used in such novels involves, first, showing us the family relationships before the coming out, then the more or less traumatic coming out period itself, and finally, some time later, we see whether and to what extent, the family/friends have adapted to the new information. The Lost Language of Cranes conforms to this pattern, but in a particularly fine and perceptive way which makes it exemplary of the genre. (206)

It is not just that Leavitt's novel exemplifies this sub-genre; for Lilly the sub-genre itself exemplifies the gay novel as a genre. While I agree with Lilly's judgment of Leavitt's novel, the "formula" for this particular kind of (post-Stonewall) novel is inappropriate for interpreting and judging what Fuller was trying to do fifty years earlier. There is no reason why we should expect Fuller in 1919 to conform to Lilly's post-Stonewall formula. When Joel Conarroe concludes his review of Bertram Cope's Year by saying that Fuller's novel is "[a]udacious for its time" (13), he is implicitly faulting it for being outdated, for not being gay enough.

This reigning paradigm of the gay novel explains why in 2014 readers of the Gay and Lesbian Review chose E. M. Forster's Maurice as the first gay novel, awarding it more votes than the next two choices combined (The City and the Pillar and The Picture of Dorian Gray). Written just a few years before Bertram Cope's Year, it was not published until 1971. In his essay on Maurice in the G\&LR, John Gorton described Forster's novel as

the prototypical gay-affirming, coming-of-age novel. [...] The theme of Maurice can be described as essentially the search for a compatible social construct by which the protagonist can understand himself and go on to self-actualization. [...] The book's publication in 1971 brought it to the attention of a newly awakened audience that could find in it a vision for actualizing the dreams of gay liberation.

It is easy to understand why readers voted for Maurice: it clearly meets their (post-Stonewall) emotional and political needs ${ }^{2}$. If, however, Bertram Cope's Year is approached with the expectation that it should fulfill these needs, it will inevitably be found less than satisfying. If the novel "treads gently around the edge of the erotic" (Solomon, 291), it refuses altogether to embrace post-Stonewall gay politics. Solomon regrets that Fuller "is always somewhat less than one would like him to be" (296), that is, less than the liberated, post-Stonewall reader would like him to be.

2 In a recent issue of The Gay and Lesbian Review, Jeffrey Round writes movingly about how as an adolescent he read Maurice, and explains why it might have saved his life. "Forster's Maurice May Have Saved My Life." G\&LR 28.1 (Jan.-Feb. 2021): 22-23. 
To understand and appreciate Fuller's novel, then, we must abandon our post-Stonewall preconceptions of what a "gay" novel is and what it must offer to be taken seriously. In spite of the fact that Fuller's novel is obviously very different in form and purpose from the coming-out novel, both readers and critics have nevertheless persistently come to it with the expectation, often only tacitly acknowledged, that it should be a character-driven psychological novel that focuses on the main character's effort to come to terms with his sexuality, accept and affirm it without guilt or shame, and "go on to self-actualization." It is scarcely surprising that such readers are disappointed. Viewed through the lens of identify politics, pre-Stonewall novels will inevitably be judged deficient. But should we impose post-Stonewall criteria on pre-Stonewall novels? We must recognize that Fuller is not writing a Bildungsroman about a gay man discovering his sexual orientation and overcoming the obstacles to its full social and sexual expression, and we should further grant that there is no reason that Fuller should be expected to have written in 1919 a novel that anticipates a post-Stonewall "vision for actualizing the dreams of gay liberation."

A defining difference between Bertram Cope's Year and novels like Maurice and The Lost Language of Cranes is that Cope and his partner Arthur Lemoyne have already accepted their sexuality before the novel begins, and they are portrayed throughout as being entirely comfortable with it. They are as "out" as they will ever be. When Bertram Cope arrives in Churchton as an English instructor and graduate student, he has been in a relationship with Arthur for close to a year, as the letter he writes to him makes clear, and there is no evidence anywhere in the text that their sexuality as such is or has been an issue for them. As Andrew Solomon observes, though without seeing the full implications of his remark, "Arthur and Bertram do not seem to find any aspect of their relationship peculiar; they never ponder on it as exclusionary, illegal, or morally suspect" (293). After they have successfully dealt with the threat to their relationship by Bertram's unexpected and unintended engagement to Amy Leffingwell, the happy lovers are able to return to their earlier bliss: "They spent ten minutes [on a walk] in the clear winter air. As Cope, on their return, stopped to put his latch-key to use, Lemoyne impulsively threw an arm across his shoulder. "Everything is all right, now," he said in a tone of high gratification; and Urania, through the whole width of her starry firmament, looked down kindly upon a happier household" (211). There are no indications of angst, shame, or self-hatred here - or anywhere else in the novel. The allusion to Urania is particularly significant. "Uranians" was a term, first introduced by Karl Heinrich Ulrichs in the 1860s and later adopted by such English writers as Edward Carpenter and John Addington Symonds, to refer to homosexual men ${ }^{3}$.

If Bertram Cope's Year is not, like Maurice or A Boy's Own Story, a coming-of-age novel, then what kind of novel is it, and what expectations should readers bring to it? To write a novel is to participate in a tradition of novel writing. No one who had never read a novel would set out to write one. And

3 See Robert Beachy's Gay Berlin: Birthplace of a Modern Identity (New York: Vintage, 2015), especially Chapter One, "The German Invention of Sexuality." How much Fuller knew of this German movement is uncertain, but the allusion to Urania is revealing. Joseph Dimuro comments, "The Uranian allusion suggests Fuller's awareness of the various codes that were available for writing about homosexuality, but it also seems clear that he was cautiously selective with regard to the developing vocabulary of same-sex attraction" (30-31). 
thus to interpret a novel accurately and to judge it fairly, readers need to known what intertextual grid they are expected to read it against. Despite its obvious difference from later gay coming-out novels, Bertram Cope's Year does share one important similarity with Forster's nearly contemporary novel. As Gorton points out, when Forster decided to write a novel with a new subject matter, he did not invent an entirely new narrative form. Rather he appropriated old forms to create "a hybrid of the traditional marriage novel and the Bildungsroman genre" (13) in which to embody his subject matter. Now the Bildungsroman and the courtship-marriage novel, a staple of nineteenth-century fiction that Forster used in his other novels, were easily amenable to his innovative subject matter but not to Fuller's. New genres are never entirely new; they are transformations of earlier ones. And so, like Forster, Fuller the novelist had to find the antecedent narrative patterns suitable for his different purpose, and he found in three genres - the campus novel, the comedy of manners, and especially the romantic comedy - the appropriate antecedent forms to tell the comic story of a homosexual man who triumphs over a society that attempts and fails to assimilate him into its marital norms.

Contemporary reviewers of Bertram Cope's Year were quick to recognize elements of the campus novel in it, even though very little of the action takes place on campus. Fuller's first biographer, Constance Griffin, complained that the novel "fails to catch the 'spirit' of university life" (66), as if that were what Fuller was trying to "catch." The college novel was a popular genre at the time; just a year after Bertram Cope's Year was published, F. Scott Fitzgerald's This Side of Paradise appeared, the first part of which recounts the hero's college years at Princeton. Fuller, however, is not writing a college novel. Instead, he appropriates and adapts this familiar form to his own purposes by incorporating two of the structural patterns that, according to Steven Connor, define the campus novel: "The one concerns the disruption of a closed world, and the gradual return of order and regularity to it, while the other concerns the passage through this closed world of a character who must in the end be allowed to escape its gravitational pull" (71). These two patterns are clearly evident in Bertram Cope's Year. Bertram's arrival disrupts the closed world of Churchton, but as the title of the novel indicates, Bertram is destined to spend only one (academic) year there. Its restrictive mores will not become his, and he, along with Arthur, escapes its "gravitational pull" towards heterosexual marriage. The novel ends with the closed, insular world of Churchton returning to its accustomed order and regularity, but that world is one that Bertram and Arthur are, Fuller implies, well rid of. They have escaped.

As a comic novel, Bertram Cope's Year is clearly indebted to the conventions of dramatic comedy. As well as a novelist, poet, and essayist, Fuller was also a playwright, and his 1896 one-act play "At Saint Judas's," boldly published just one year after Oscar Wilde's trials, is widely recognized as the first American play on a homosexual theme ${ }^{4}$. Writing about Fuller in 1925, Charles C. Baldwin remarked,

\footnotetext{
${ }^{4}$ The play is included in the Broadview Press edition of Bertram Cope's Year, edited by Joseph A. Dimuro. It is also available on line at Internet Archive: https://archive.org/details/puppetboothtwel01fullgoog
} 
"He is familiar with Marlowe's mighty lines and the terrific tragedies of Kyd. He knows farces in which [David] Garrick played and the comedies of Molière" (190). Not surprisingly, then, there are numerous references in Bertram Cope's Year to acting and the theatre, including allusions to Sophocles' Antigone and Schiller's Wallenstein. Bertram, who is considering writing his M.A. thesis on Shakespeare, is named after the hero of All's Well That Ends Well, and his sister, Rosalys, is confused with Rosalind in As You Like It. Either of those titles would make a fitting subtitle for the novel. All the major characters are, to varying degrees, playing roles. Arthur is an actor who plays a female role (in full drag, no less!) in the college dramatic society's production of The Antics of Arabella. Dramatic comedy, it is pertinent to note, has a long history of cross-dressing.

As an actor, Arthur relies on his memory of the plays he has acted in to help Bertram get out of his engagement. The letter he composes for Cope to send to his fiancée, breaking off their engagement, is modeled on similar letters that Arthur recalls from plays. His mind, we are told,

was full of clichés from his reading and from his "scripts." He had heard all the necessary things said: in fact, had said them himself - now in evening dress, now in hunting costumes, now in the loose habiliments of Pierrot - time and time again. The dissatisfied fiancé need but say that he could not feel, after all, that they were as well suited to each other as they ought to be, that he could not bring himself to believe that his feeling for her was what love really should be, and that - (209)

Arthur's letter perfectly illustrates Oscar Wilde's critical axiom that life imitates art, a truth that is further confirmed when Bertram's fiancée Amy preempts Arthur's conventional letter breaking off Bertram's engagement by sending him a similarly worded letter of her own containing the very same clichés: "'She says what you say!' exclaimed Cope with shining eyes and a trace of half-hysteric bravado. 'She does not feel that we are quite so well suited to each other as we ought to be, nor that her feeling toward me is what love really [...] Can she have been in dramatics too!'" (210). In Fuller's comedy all the characters have their prescribed roles to play, and consequently readers unfamiliar with the comic tradition will miss much of the pleasure of this conventional comic novel that also subverts conventions - both literary and (as we shall see) sexual.

The comic plot of the novel reverses - and subverts - the standard plot of romantic comedy, which typically focuses on a pair of lovers whose union is thwarted by a blocking character, such as the heroine's father or guardian, whose obstruction is finally overcome, allowing the happy couple to proceed to the hymeneal altar. (This pattern goes back to the Roman comedies of Terence and Plautus.) In Fuller's clever reworking of the formula, the (male) lovers are already together when the action begins and their happy union is threatened by the matrimonial machinations of, Medora Phillips, the widow of an artist and art collector and Churchton's preeminent socialite. Fuller's comic plot puts the lovers' stable relationship in danger when three young, talented women - The Three Graces, as Bertram dubs them in a letter to Arthur - as well as one middle-aged gay man threaten it. 
Medora is cast in the role of the blocking character as she seeks a suitable wife for Cope, Churchton's newest eligible bachelor.

When Bertram finds himself unexpectedly engaged to Amy Leffington as a result of a boating accident in which Amy portrays Bertram as the hero who saves her (actually, she saves him), it gives the resourceful Arthur the incentive to leave Winnebago, Wisconsin, where the two met when Bertram was teaching there the previous year, and join him in Churchton. The comic plight of an endangered Bertram is explicitly signaled by many of the chapter titles: "Cope Shall Be Rescued," "Cope Regains His Freedom," "Cope in Danger Anew," "Cope in Double Danger," "Cope Escapes a Snare." It is this comic form - an unheroic and matrimonially imperiled hero rescued at the eleventh hour - that governs the novel's innovative plot structure. As a comic novel that blends the romantic comedy and the comedy of manners, Bertram Cope's Year does not focus on Cope's struggle to accept and then affirm his sexuality, but rather on how Cope successfully overcomes the threat to his relationship with Arthur arising from the efforts of the provincial society of Churchton, embodied in the formidable Medora, to force him into an unwanted marriage. Medora Phillips is a character type familiar in comedies of manners. She is a literary descendant of Lady Bracknell in Wilde's The Importance of Being Ernest. The innocent and inexperienced Bertram is initially outmanoeuvred by Medora - her name, of Greek origin, means "ruler" - and she rules Churchton society like a Greek tyrant. (In her first encounter with Cope, she peremptorily orders him to fetch her some refreshments, as if he were a servant.) The inexperienced Bertram sees no way of getting out of the unwanted engagement and spending the rest of his life in Churchton - until Arthur arrives to save him.

It is not just Medora's protégées, the Three Graces, who threaten Bertram. At the same time as the main plot of impending heterosexual marriage is unfolding, Bertram is also being amorously pursued by the middle-aged and sexually diffident Basil Randolph ${ }^{5}$. While Bertram is planning to set up a ménage-à-deux with Arthur, Randolph, a wealthy, middle-aged stockbroker, scholar manqué and friend of Medora Phillips, takes a fancy to Cope and in pursuit of him is eagerly acquiring a larger, well-appointed apartment (complete with a cook) that he hopes will entice the disappointingly reluctant Bertram to acquiesce to sleepovers and - dare he hope? - perhaps more! Randolph has a passion for collecting curios, antiques, objects d'arts - and attractive and youthful college boys:

The least old of all things in Randolph's world were the students who flooded Churchton. There were two or three thousand of them, and hundreds of new ones came with every September. Sometimes he felt prompted to "collect" them, as

\footnotetext{
${ }^{5}$ Basil shares his Christian name with Basil Halliwell, the artist whose infatuation with the beauty of Dorian Gray leads him to paint his picture. In Fuller's novel, Hortense Dunton, the niece of Medora Phillips and one of the Three Graces, is in love with Cope and starts to paint his picture but never finishes it. The uncompleted portrait represents Hortense's failure to win Bertram's love - she can't figure out how to capture him on canvas - and the doomed relationship between the two may be Fuller's covert allusion to the doomed affair between Dorian Gray and the actress Sybil Vane. Bertram's youth and beauty, like Dorian's, elicit the same intense erotic response in both men and women. These multiple allusions to Wilde's novel, hitherto unnoticed by critics, are too insistent to be unintended.
} 
contrasts to his older curios. They were fully as interesting, in their way, as brasswork and leatherwork [...]. (31)

His carefully planned "courtship" of Cope includes an excursion to the Big Town (Chicago) for dinner and a play. Fuller handles the intrigues and misunderstandings arising from these twin romantic plots with a sureness, subtlety, and lightness of touch that is one of the many charms of this "light, bright and sparkling" comic novel.

Once the crucial importance of the novel's comic form is recognized, the widespread criticism of Fuller's portrayal of Bertram's character can be seen as a failure to appreciate Bertram's role as the comic hero of the novel. Although comic novels rarely focus on the psychological complexity of their protagonists - characters in comedies tend to belong to recognizable types - much criticism of Bertram Cope's Year is directed at the alleged weakness of Bertram's characterization, which in turn is seen as an artistic flaw in the novel. This criticism arises, as we have seen, primarily from the expectation that the central character in a gay novel needs to be psychologically complex, and especially from the presupposition that a gay novel ought to depict the struggle of the protagonist to affirm his identity as a gay man in a society that resists such an affirmation.

The criticism of Cope's characterization and, by extension, of the novel begins with Edmund Wilson, who argues that Fuller's portrayal of Cope undermines his effort

to dramatize convincingly the spell of enchantment he is supposed to cast. This is seen in his effect on the other characters, but the reader is not made to feel it: Bertram is represented as behaving in an agreeable enough way, but in his selfcenteredness, he never does anything that is made to seem really attractive. And the result $[. .$.$] is a kind of deliberate flatness. (x x x)$

This fault, Wilson concludes, renders Cope "intrinsically uninteresting" (xxx).

Two decades after Wilson, Solomon, despite his praise of the novel, continues to focus on the characterization of Bertram as the source of the novel's weakness:

Bertram Cope is a man without real qualities and feelings, and feelings themselves are quite alien to him. He never has a flash of admirable passion. Unintentionally, he disappoints or injures everyone, and he leaves in his flat wake a trail of flat destruction [...] . [The novel] is about the impossibility of achieving intimacy when one is drawn to chilliness (Fuller compares Bertram more than once to an icicle). What may appear to be understatement and a cautious stepping back from the frightening cold water may in fact be simple selfishness. (299) 
Virtually all of these criticisms of Bertram arise from misreadings. Bertram is certainly not "a man without real qualities and feelings." He does not possess a "hard, self-sufficient core of character." Nor is he "intrinsically uninteresting," or "drawn to chilliness," or self-centered, or incapable of achieving intimacy. None of these are intrinsic character flaws. Rather they are flaws attributed to him by the other characters as a result of their misperceptions of his lack of interest in women and of his sexual relationship with Arthur. This criticism of him is first expressed by Medora Phillips to Randolph when Cope fails to show any romantic interest in her "poor girls":

"He sings," said Medora [...] . "Entertained us the other Sunday afternoon. Cool and correct, but pleasant. No warmth, no passion. No special interest in any of my poor girls. I didn't feel that he was drawing any of them near the danger line." (34)

In contrast, Arthur certainly does not find Cope uninteresting or lacking in feeling. If "feelings [...] are quite alien to him," if he really did have a "hard, self-sufficient core of character," would Arthur have fallen in love with him? And if Bertram never had "a flash of admirable passion," would he have fallen in love with Arthur?

The obvious reason that the reader does not, like the three young women, feel Cope's "spell of enchantment" is that the reader knows what Medora and her three protégées do not know: that Cope is homosexual and in a fulfilling relationship with Arthur. The reader is far more aware of the depth of that relationship than any of the characters. Cope's lack of romantic interest in Medora Phillips' three young protégées arises not from his coolness or lack of warmth, or from his "hard, selfsufficient core of character" (Wilson xxx), but from what today we would call his sexual orientation. The three young women who are attracted to him obviously do not know that his lack of romantic interest in them arises not from an intrinsic emotional deficiency, or from his inability to achieve intimacy - he certainly achieves intimacy with Arthur - but rather from the simple fact that, as a gay man with a devoted boyfriend, he obviously has no romantic attraction to women and, moreover, is incapable of such an attraction. Contemplating what appears to be unavoidable marriage to Amy, Cope muses, "Most of all he saw - and felt to the depths of his being - his own essential repugnance to the life toward which he now seemed headed" (176; italics added). As this description of his feelings reveals, Cope obviously is capable of strong feelings, although the other characters, except for Arthur, have no access to them.

As a gay man in a relationship with a man, Cope has never had any experience of or interest in heterosexual courtship. Relating romantically with women demands, as Bertram acknowledges to Randolph, "a knack [...] a technique - that I don't seem to posses. Nor do I seem greatly prompted to learn it" (76). But the reason he is not prompted to learn it is not that he is incapable of intimacy. Lacking this technique or knack with women is not equivalent to being incapable of intimacy. His failure to respond emotionally to the three women has nothing to do with his coolness, self-centeredness or lack of feeling. If it were he would not be in a relationship with Arthur. According to Solomon, 
the novel is about "the impossibility of achieving intimacy when one is drawn to chilliness (Fuller compares Bertram more than once to an icicle)" (299). Bertram is not drawn to chilliness. We are repeatedly shown examples of the intimacy between Bertram and Arthur.

The serio-comic situation Cope suddenly and unexpectedly finds himself in arises not only from his own inexperience but also from a historical situation (a common one in Fuller's time and for decades afterwards) in which a closeted gay man of marriageable age has to negotiate his relations with women, especially unmarried ones in search of a husband, within a society that assumes him to be heterosexual and therefore naturally in search of a wife. (This was less of a problem for the middleaged gay man who, like Basil Randolph, is stereotypically perceived as a "confirmed bachelor.") Today, someone in Bertram's position would much more likely be "out" - especially in the tolerant, liberal environment of a university - and therefore the awkward situation Bertram finds himself in would be much less likely to arise. (It's virtually impossible to imagine the story of Bertram Cope's Year being set in 2019.) Today, if a young, handsome man of marriageable age is not dating and shows no signs of romantic interest in women, then most people - especially today's equivalent of Bertram's circle of acquaintances - would be predisposed to assume that he is gay rather than 'a confirmed bachelor' - especially if he were in a relationship anything like the one between Bertram and Arthur.

The misinterpretations of Bertram as cool, unfeeling, and self-centered also arise from a failure to perceive Fuller's strategic use of focalization in the novel. Solomon, for example, erroneously assumes that the perception of Bertram as someone "drawn to chilliness" is Fuller's representation of him, and hence one that the reader is supposed to endorse: "Fuller compares Bertram more than once to an icicle" (Solomon, 299). But this is simply not true. Solomon has confused the other characters' judgments of Cope with the narrator's and hence with Fuller's. The reader rarely has direct access to Bertram's consciousness (his letter early in the novel to Arthur and the revelation of his feelings about marrying Amy are the rare exceptions.) It is the characters in the novel - not the narrator or Fuller who describe Cope as cool, unfeeling, remote, and self-centered. Consider, for example, the repeated comparison of him to an icicle. Early in the novel Basil Randolph reports to his friend Joe Foster his first encounter with Bertram at one of Medora's parties, and Foster asks if Bertram sang with passion. Randolph replies, "Well, hardly. With cool correctness. An icicle on Diana's temple - that would be my guess." Randolph is describing the musical voice with which Cope sang a particular "really good" song at Mrs. Phillips's salon. Randolph is not evaluating Cope's character, only his musical performance on that occasion as a singer. Moreover, he explicitly says that his interpretation of Bertram's voice is only a "guess," not an objective judgment. So we should not take Randolph's words as a disinterested and hence reliable assessment of Bertram's character endorsed by Fuller. Bertram's coolness towards Randolph arises partly from the fact that he knows that Randolph is sexually attracted to him and does not want to encourage the older man. 
The comparison of Cope to an icicle reappears later in the novel during a trip to the opera. Mrs. Phillips wonders just what it is that makes Cope so attractive to her:

He looked well as he sat on the back seat of the limousine with Medora Philips, during the long drive in; and he looked well - strikingly, handsomely well - in the box itself, Indeed, thought Medora, he made other young men in nearby boxes young men of "means" and "position" - look almost plebian. "He is charming," she said to herself, over and over again.

What about him took her? Was it his slenderness, his grace? Was it his youthfulness, intact to this moment and promising an extension of agreeable possibilities into an entertaining future? Or was it more largely his fundamental coolness of tone? Again he was an icicle on the temple - this time the temple of song. "He is glittering," said Medora, intent on his blazing blue eyes, his beautiful teeth ever ready for a public smile, and the luminous backward sweep of his hair [...] . (214)

We view Cope here entirely from Medora's point of view, not the narrator's or Fuller's. It is Medora, not the narrator or Fuller, who compares Bertram to an icicle. She is the focalizer, and the passage reveals far more about Medora than Cope. Significantly, we are not privy to Cope's thoughts here. The passage provides no insight into Cope's feelings; it is Medora's mind we peer into. So there is no justification for inferring that he is in fact as cool as an icicle, or that coolness is a "fundamental" quality of his nature. The fact that he does not feel passion for a middle-aged woman does not mean he lacks passion.

Criticism of the novel has, understandably, tended to focus attention primarily on Bertram, but an appreciation of its complex design, and especially its representation of the erotic, must pay attention to Arthur Lemoyne's important role and to the couple's relationship. For not only is Arthur cast in the role of Cope's rescuer, he is also the character who infuses the erotic into a novel that, according to Solomon, "treads gently around the edge of the erotic" (291). Granted, the novel lacks the explicit representation of sex and sexual feelings we find in post-Stonewall novels. But we must not therefore conclude that Fuller is repressing the erotic ${ }^{6}$. He has, in fact, successfully found a way to express it. There are three erotic scenes in the novel, and they are carefully sequenced so as to build climactically towards the scene in which Arthur, after a performance of The Antics of Arabella, kisses one of the male actors. The sequence begins with the nude swimming scene, which Joel Conarroe calls "unexpected" and insists that it "includes no hint of surreptitious voyeurism" (13). The scene might

\footnotetext{
${ }^{6}$ For a Freudian interpretation of sexual repression in the novel, see Keith Gumery, "Repression, Inversion and Modernity: A Freudian Reading of Henry Blake Fuller's Bertram Cope's Year. Journal of Modern Literature 35.3/4 (Summer 2002), pp. 4057.
} 
initially seem to be "unexpected," but it is clearly part of Fuller's artistic design. It subtly foreshadows the subsequent scenes in which the erotic becomes increasingly more pronounced.

During their swim in Lake Michigan while visiting Medora's summer cottage, Cope and Randolph discuss marriage, and Cope, who fears that marriage will be a trap for him, remarks, "I'm pretty sure to get caught some time or other" - Chapter 27 is called "Cope Escapes a Snare" - to which Randolph responds, "You're manoeuvred into a position where you're made to feel you 'must.' I've know chaps to marry on that basis" $(76,77)$. Cope's remark that he will likely "be caught" should be interpreted not as evidence that Cope is ambivalent about his sexuality, but rather as a revelation of his fear that one day he "must" succumb to the social pressure to get married. That, in fact, is what almost happens to Cope later when he finds himself engaged to Amy and feels that he "must" marry her. Since at this point in the novel, gay readers know that Bertram is gay, the fact that Cope's conversation with another gay man occurs in the course of a nude swimming scene adds a covert sexual frisson to the discussion of how a gay man in 1919 should deal with the social expectation that he must eventually marry. While there is no hint of voyeurism, the nude swimming scene subtly alludes to the fact that one of the ways in which homoeroticism could be acceptably expressed in the late nineteenth and early twentieth century was through paintings of nude youths, as the paintings of Henry Scott Tuke demonstrate ${ }^{7}$.

Although the sexual relationship between Bertram and Arthur could not in 1919 be explicitly portrayed in the novel, Fuller circumvented this obstacle through his erotically charged representation of the duet they sing at one of Mrs. Phillips' evening receptions. It is difficult not to take Fuller's description of their impassioned rendition of the nautical ballad "Larboard Watch" as a bold metaphor for sexual consummation:

Lemoyne felt the composition to be primitive, antiquated and of slight value; but he had received his cue, and both his throat and his hands wrought with an elaborate expressiveness. He sang and played, if not with sincerity at least with effect. His voice was a high, ringing tenor; not too ringing for Cope's resonant baritone, but almost too sweet: a voice which might cloy (if used alone) within a few moments. Cope was a perfect second, and the two went at it with a complete unity of understanding and of sentiment. Together they viewed - in thirds - "the gath'ring clouds;" together - still in thirds - they roused themselves "at the welcome call" of "Larboard watch ahoy!" Disregarding the mere words, they attained, at the finish, to something like feeling - or even like a touch of passion. (192-93)

\footnotetext{
7 See Flora Doble, "Henry Scott Tuke: Capturing Light and the Homoerotic Gaze." ArtUK. org <https://artuk.org/discover/stories/henry-scott-tuke-capturing-light-and-the-homoerotic-gaze> Accessed February 16, 2021. (Fuller and Tuke were born one year apart and died in the same year.)
} 
The description of the duet (Fuller was an amateur musician) abounds in double entendres: "the two went at it," "Together," "complete unity," "together," "they roused themselves," "they attained, at the finish [...] a touch of passion." Significantly, when Cope sang solo earlier in the novel at another of Medora's parties, his performance was far more restrained: "He sang with care rather than with volume, with discretion rather than with abandon [...] as if some temperamental brake were operating to prevent the complete expression of the singer's nature" (24; italics added). In reporting the event to Basil Randolph, Cope tells him, "I do best with my regular accompanist" (55). His "regular accompanist" is, of course, Arthur, and when he sings the passionate duet with him there is no "brake" on the "complete expression" of his true nature. In 1919 Fuller would not have been free to directly describe sex between two men, but in the duet sung by the two lovers he finds the perfect vehicle to express it indirectly.

On this occasion Medora recognizes something she has not seen before in Cope's singing, which she had earlier (before the arrival of Arthur in Churchton) described as "cool and correct, but pleasant. No warmth, no passion." Significantly, she immediately follows this assessment of Cope's singing by complaining about his lack of romantic interest in the Three Graces: "No special interest in any of my poor girls. I didn't feel that he was drawing any of them too near the danger-line" (34). Yet when he sings the duet with Arthur, he does more than draw near the danger line - he crosses it. "Medora Phillips," we are told, "had never heard Cope sing like that before; had never seen so much animation in his singing face. By the fourth bar there had been tears in her eyes, and there was a catch in her breath when she exclaimed softly, "You dear boys!" (193). Dear boys, indeed! Beneath the novel's placid surface there runs an undercurrent of suppressed - not repressed - sexual passion that critics have failed to fathom. Novelists and film makers have always found ways to get around the censor. The duet here reminds me of the memorable scene in Michael Gordon's Pillow Talk (1959) in which Rock Hudson and Doris Day flirt on the phone while, on the split screen, each is taking a bath. Sex will always out. Had the novel been made into a film, the perfect scriptwriter and director would have been the Billy Wilder of Some Like It Hot (1959).

The submerged sexual undercurrent running through the novel - prefigured by the nude bathing scene and intensified by Bertram and Arthur's duet - finally erupts, boils over, after a performance of the farcical comedy The Antics of Arabella in which Arthur has a role impersonating a female character. "This is the gay life," Arthur exclaims shortly after arriving in Churchton, "just the life I have come down here to lead" (208). His performance of the role is such a success that he cannot restrain himself from sharing his pleasure in it with another actor: " [...] in his general state of ebulliency he endeavoured to bestow a measure of upwelling femininity upon another performer who was in the dress of his own sex" (270). (The word "ebullient" comes from the Latin ebullire, to boil over, an etymology Fuller would certainly have known.) Kept on the back burner until now, the erotic, embodied in Arthur (his name is a pun on art), suddenly boils over. Both the university and the town are 
scandalized by the incident and Arthur is expelled from the dramatic society, loses his job at the university, and is forced to return to Winnebago.

To understand the significance of this scene both for the representation of homosexuality and for the expression of the erotic in the novel, we need to look more closely at the (sexual) relationship between Bertram and Arthur, and especially at Fuller's decision to portray Arthur as the primary locus of the erotic. Although the university and the town of Churchton are shocked by Arthur's scandalous "antics," their moralistic reaction needs to be balanced by Fuller's portrayal - and approval - of Arthur's sexuality. A clue to Arthur's role in the novel is provided by the non-judgmental and affirming reaction to Arthur and his relationship with Bertram by the members of the Cope family, especially Bertram's sister Rosalys:

Lemoyne presented himself to the combined family gaze as a young man of twenty-seven or so, with dark, limpid eyes, a good deal of dark, wavy hair, and limbs almost too plumply well-turned. In his hands the flesh minimized the prominence of joints and knuckles, and the fingers (especially the little fingers) displayed certain graceful, slightly affected movements of the kind which may cause a person to be credited - or taxed - with possession of the "artistic temperament." To end with, he carried two inches of short black stubble under his nose. He was a type which one may admire - or not. Rosalys Cope found in him a sort of picturesque allure. Rather liking him herself, she found a different reason for her brother's liking. "If Bert cares for him," she remarked, "I suppose it's largely by contrast - he's so spare and light-colored himself. (183)

The first thing to notice here is that we view Arthur from the Cope family's perspective: "Lemoyne presented himself to the combined family gaze [...] ." At the same time, Fuller carefully balances the disapproving and the approving responses to Lemoyne, as the phrases "credited - or taxed" and "admire - or not" reveal. Especially relevant to Fuller's subtly subversive representation of Arthur is the implied contrast between Rosalys's response to Arthur's "artistic temperament" and that of the characters in Churchton. For Rosalys, who finds in her brother's friend "a sort of picturesque allure," it is sufficient that her brother "care for" Arthur in order for her to approve of him. Moreover, in calling attention to the physical differences between Bertram and Arthur, she also, even if only unconsciously, recognizes - and significantly does not condemn - their mutual sexual attraction. It should also be pointed out that Bertram's father "came to look upon him [Lemoyne] as an able, if somewhat fantastic, young fellow" (185). The father's "fantastic" is a variation on Rosalys's "sort of picturesque." Fuller carefully contrasts the approving response of Bertram's Freeford family to Arthur with that of the disapproving Churchtonians, who find him effeminate. In post-Stonewall gay novels, the family is often the primary source of the conflict and resistance that the protagonist must confront and eventually resolve. Cope's family, in contrast, is completely accepting of the relationship between the two men. (I am reminded of Robert Ferro's 1984 novel The Family of Max Desir, in which Max's family slowly comes to accept his relationship with his partner Nick Flynn.) Finally, the 
contrasting connotations of the names of the two towns, which Fuller has carefully chosen, Churchton and Freeford, are very revealing. It is impossible to imagine Fuller reversing the towns' names.

Critics have tried to account for Arthur's scandalous behaviour and subsequent expulsion from Churchton by interpreting it as evidence of Fuller's attempt to retreat from the whole issue of homosexuality. Scambray, for example, argues that

Fuller uses Arthur's female costume and the backstage incident to draw the homosexual theme closer to the surface of his story. [...] But the incident becomes not a means to explore further the homosexual theme, but rather the very excuse Fuller needed to complicate and even cloud Cope's relationship with Arthur. [...] Arthur is separated from Cope, and because of the embarrassment Arthur has caused everyone, in the end Cope breaks off his relationship with his impetuous friend. To complicate matters further, Fuller attempts to relieve Cope of any suspicion in his affair with Arthur. (151)

He goes on to claim that as a result of Arthur's behaviour Cope learns "something about Arthur's character, presumably his homosexuality that Cope had not known before" (151). He also claims that Fuller "caves into social pressure," calling the sacrifice and banishment of Arthur a "kind of atonement even an attempted retraction of much of what Fuller had initially developed in Cope's character" (151). Conarroe takes a similar view, describing Arthur as " [...] the one character who comes to grief. His fate may well offer a clue to the author's restrained, indirect approach to erotic feelings and actions. Fuller was clearly not oblivious of the era's assumptions [...] that any sort of 'perversion' must necessarily be associated with guilt, disgrace and even punishment" (13). Even Joseph Dimuro, whose reading of the novel is clearly indebted to recent queer theory, argues that "Lemoyne neglects to separate his female stage persona from his real life off stage, in which he assumes what might be called a 'fairy' persona that repulses a (presumably) straight man," adding that the 'theatrical aspects of Lemoyne's personality repel Cope as well" (Dimuro, "Introduction," 33). This view is endorsed by Keith Gumery's Freudian reading of the novel ${ }^{8}$.

These interpretations exemplify the current orthodoxy that Lemoyne's impetuous action reflects Fuller's effort to pull back from the homosexual content of the novel. However, the fact that Fuller is "restrained" in his representation of erotic feelings and actions is not evidence that he is trying "to minimize the homosexual content of the novel." The problem with all these readings is that they are not supported, and are even flatly contradicted, by the evidence in the text. Moreover, they fail to

\footnotetext{
${ }^{8}$ In Gumery's view, "Lemoyne's behavior threatens the construct of acceptability that has been so carefully put together by Randolph and his kind [of repressed homosexual]; if Lemoyne and Randolph are seen to be of the same 'type,' then the danger to Randolph's position in society, caused by association [with homosexuals like Lemoyne], becomes tangible. In very much the same way, Henry Blake Fuller's position within his society could also be threatened were he (as Harriet Monroe put it) 'to tell his whole story.' By writing this book, and creating Arthur Lemoyne as a foil, Fuller could [...] show how the kind of action and appearance demonstrated by Lemoyne should be dealt with" (57).
} 
perceive that Fuller, in opposition to the scandalized Churchtonians, is in fact implicitly endorsing Arthur's transgressive behaviour. It is impossible to believe, as Scambray claims, that only at the end of the novel does Cope realize that his Arthur is homosexual. Fuller is not "ambivalent" in his treatment of homosexuality. Nor is he trying "to complicate and even cloud Cope's relationship with Arthur." Although Solomon recognizes that "Arthur has a Wildean streak, and Bertram goes in for cautious restraint" (292), he fails to grasp the full implications of Arthur's "Wildean streak." The narrator remarks that Arthur's actions "are the risks run by the sincere, self-revealing artist" (271), and it is through Arthur that Fuller introduces a Wildean transgressiveness into his novel. The climactic placement of the erotic "antics of Arthur" gives the staid and conformist Churchtonians the comeuppance they so obviously deserve.

Nor is it true, as Scambray asserts, that "Cope breaks off his relationship with his impetuous friend," or that the letter Cope sends to Carolyn at the end implies that he has rejected his homosexual relationship with Arthur and plans to marry her:

This letter and Cope's implied interest in a female after all were Fuller's way of setting out a smoke screen, of deflecting attention from his homosexual theme [...]. That he was finally ambivalent in his treatment of [homosexuality] in Bertram Cope's Year reflects his lifelong conflict with society; his desire to tell his whole story while at the same time maintaining his respectability in the eyes of his friends and readers [...]. The risks in 1919 were still too great for the homosexual writer. (Scambray, 152)

Cope does not, in fact, end his relationship with Arthur. We are explicitly told that Arthur "returned to Winnebago a fortnight before the convocation [...] and it was the understanding that, somehow, he and Cope should share together a summer divided between Winnebago and Freeford" (272). Nor does Cope's letter to Carolyn imply, as Medora Phillips believes, that Cope has any matrimonial interest in Carolyn. Scambray has failed to perceive Fuller's obvious irony. Addressed to "My dear Miss Thorpe," - his letter to Arthur early in the novel begins "Dear Arthur" - the letter, consisting of "two small pages," is cool, formal, and matter-of-fact in tone:

"Yours very sincerely, Bertram L. Cope" simply told "My dear Miss Thorpe" [no first name] that he had been spending three or four days in Winnebago, Wisconsin [visiting Arthur], and that he had now retuned home [to Freeford] for a month of further study, having obtained a post in an important university in the East, at a satisfactory stipend. A supplementary line conveyed regards to Mrs. Phillips. That was all. (282)

If Bertram really were intent on rekindling Carolyn's affection for him and intimating the likelihood of marriage, would he mention that he has just spent several days in the company of the man whose behaviour had so scandalized the university and Churchton that he was banished? Surely the obvious 
implication - to the reader if not to the willfully blind Amy and Medora - is that now that "Bertram T. Cope" has "a satisfactory stipend" he will be sending not for Carolyn but for Arthur to join him in the East, just as he had earlier asked him to come to Churchton. The careful designation of the eastern university as "important" clearly implies that the college in provincial Churchton is rather less important. When Carolyn shows the letter to Mrs. Phillips, it is described (by the narrator) as "a brief, cool, succinct thing, and not at all unsuited for general circulation" (283). Again, would a letter intended to express Cope's romantic feelings for Carolyn, assuming he had any, be suitable for general circulation? After Mrs. Phillips reads the letter, "she retired for meditation," and what follows is a transcription, in free indirect style and laced with irony, of her willful misreading of it:

Well, from his dozen or fifteen lines several things might fairly be inferred. "Three or four days in Winnebago" - a scanty pattern for a visit. Had three or four been enough? Had Lemoyne been found glum and unpleasant? Had those months of close companionship [in Churchton] brought about a mutually diminished interest? Not a word as to Lemoyne's accompanying him to Freeford [where Cope's family lives], or joining him there later. On the contrary a strong implication that there would be sufficient to occupy him without the company of Lemoyne or anybody else: evidences of an eye solely on the new opportunity in the East."

"Well, if he [Bertram] is going to get along without him [Arthur]," said Medora to herself, "it will be all the better for him," she added, with an informal and irresponsible use of her pronouns. But she knew what she meant and had no auditor to satisfy. (283)

The "several things" she infers would certainly not be inferred by an alert reader attuned to Fuller's obvious irony. Medora - scarcely the most perceptive character in the novel - wildly imagines that the letter will initiate an exchange of letters between Cope and Carolyn, ending in a marriage proposal from Cope. Medora's questions, speculations and conclusions are hers alone, not the narrator's, and she is determined to make what Cope says, as well as what he does not say, confirm her absurd hopes that marriage to Carolyn is still a real possibility. "She will marry him," she confidently tells Randolph (287), and then goes on to imagine an extended correspondence between them, leading to marriage.

Randolph undermines Medora's unjustified optimism by composing an imaginary letter to himself from Cope, as brief, cool and formal as Cope's to Carolyn and much more believable than Medora's invented correspondence between Cope and Carolyn:

"My dear Mr. Randolph, - You will be pleased, I am sure, to hear that I now have a good position at the university in this pleasant town. Arthur Lemoyne, whom you recall, is studying psychology here, and we are keeping house together. He wishes 
to be remembered. I thank you for your many kindnesses," - that is put in as a possibility, - "and also send my best regards to Mrs. Phillips and the members of her household. Sincerely yours, Bertram L. Cope." (287)

The ironic tone, bordering on sarcasm, of Randolph's imagined letter reveals that he clearly recognizes what Medora does not: that Cope's succinct, curt, formal letter to Carolyn is his polite but firm way of severing all his links with Churchton, and letting his former acquaintances, including Medora and Randolph, know that now that he has moved up in the academic world, they are all irrevocably consigned to his soon-to-be-forgotten past. The three letters - Bertram's to Arthur (which was sent), Bertram's to Amy (composed by Arthur but never sent), and Bertram's letter to Randolph (wholly imagined by Randolph) - are all crucial to understanding the true relationships among the characters and, furthermore, offer evidence of the subtleties of Fuller's art of fiction. As a romantic comedy, the novel does have a happy, although unconventional, ending: Cope escapes from the danger of spending the rest of his life unhappily married in Churchton.

A few years after Bertram Cope's Year was published, John Farrar wrote about it in his column in The Bookman: "It is a story delicately done with the most exquisite taste, of a sublimated irregular affection. It received scant and unintelligent notice from the reviewers, and though it was filled with dynamite scrupulously packed, it fell as harmless as a dud, only to be whispered about here and there by grave people who wondered why Mr. Fuller should choose such a theme" (649). Bertram Cope's Year is not about "a sublimated irregular affection," although Farrar may be using that quasi-medical term non-judgmentally. The affection between Arthur and Bertram is certainly not sublimated. However, Farrar's insight that the novel is "filled with dynamite scrupulously packed" is, in my judgment, one of the most perceptive remarks ever made about the deftness and subtlety, the complete mastery of form, with which Fuller handles his potentially explosive theme. So scrupulously has Fuller packed his dynamite with stabilizers that readers have detected scarcely a whiff of the explosive nitroglycerin. Fuller has expertly packed the subversive dynamite in his novel, counting on the perceptive reader to light the fuse. Bertram Cope's Year is one of the earliest novels to portray a gay man's successful resistance to the pressures of a parochial society to subject him to its marital norms. It is also one of the wittiest gay novels in the canon, its innovative comic form perfectly adapted to its subtly subversive treatment of what then was still a taboo subject. For its perfect fusion of comic form and subversive theme, it deserves permanent currency.

\section{Works Cited}

Austen, Roger (1977), Playing the Game: The Homosexual Novel in America, New York, BobbsMerrill.

Baldwin, Charles C. (1925), The Men Who Write Our Novels, Revised Edition, New York, Dodd, Mead, and Company.

Bowron, Bernard R., Jr. (1974), Henry B. Fuller of Chicago: The Ordeal of a Genteel Realist in an Ungenteel America, Westport, Greenwood Press. 
Connor, Steven (1995), The English Novel in History, 1950-1995, London, Routledge.

Conarroe, Joel (1998), "Seven Types of Ambiguity", 9 August, The New York Times Book Review. 103: 13.

Dimuro, Joseph A. (2010), Introduction to Bertram Cope's Year, Peterborough, Broadview Press.

Farrar, John (1924), "The Literary Spotlight", February, The Bookman, 58: 645-49.

Fuller, Henry Blake (1998), Bertram Cope's Year, New York, Quality Paperback Book Club.

(1917), "The Plea for Shorter Novels", 3 August, Dial, 63: 139-141.

Gorton, John (2014), "While Maurice Slept", Lesbian and Gay Review, 21.6: 13-16.

Griffin, Constance M. (1939), Henry Blake Fuller: A Critical Biography, Philadelphia, University of Pennsylvania Press.

Gumery, Keith (2002), "Repression, Inversion and Modernity: A Freudian Reading of Henry Blake Fuller's Bertram Cope's Year", Journal of Modern Literature, 25.3/4: 40-57.

Lilly, Mark (1993), Gay Men's Literature in the Twentieth Century, London, Macmillan.

Pilkington, John Jr. (1970), Henry Blake Fuller, New York, Twayne Publishers.

Scambray, Kenneth (1987), A Varied Harvest: The Life and Works of Henry Blake Fuller, Pittsburg, University of Pittsburg Press.

Solomon, Andrew (1998), "Afterword", Bertram Cope's Year, Henry Blake Fuller, New York, Quality Paperback Book Club: 289-300.

Van Vechten, Carl (1926), Excavations: A Book of Advocacies, New York, Alfred A. Knopf: 289-299.

Wilson, Edmund (1998), "Henry Blake Fuller: The Art of Making It Flat", Bertram Cope's Year, Henry Blake Fuller, New York, Quality Paperback Book Club, 1998: ix-xxxiv. 